\title{
Narcea-an unknown, ancient cultivated rose variety from northern Spain
}

\author{
María-Carmen Martínez (1)', José-Luis Santiago [1]', Susana Boso (1)', Pilar Gago (1)', Inmaculada Álvarez-Acero²,

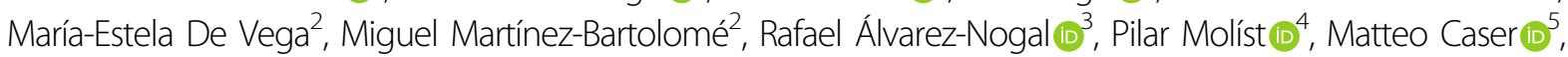 \\ Valentina Scariot (i) ${ }^{5}$ and Daniel Gómez-García ${ }^{6}$
}

\begin{abstract}
The present work reports the discovery and the complete characterisation of an ancient cultivated rose variety found growing in a private garden in the southwest of the Principality of Asturias (northern Spain). The variety is here given the name Narcea. The majority of roses currently cultivated belong to the so-called group of 'Modern Roses', all of which were obtained after 1867 via artificial crosses and improvement programmes. All are destined for ornamental use. Until the 19th century, the great majority of the many ancient cultivated roses in Europe were used in perfumery and cosmetics, or had medicinal uses. Rosa damascena and Rosa centifollia are still grown and used by the French and Bulgarian perfume industries. The Asturian Massif of the Cantabrian Mountain Range provides a natural habitat for some $75 \%$ of the wild members of the genus Rosa, but until now there was no evidence that this area was home to ancient cultivated roses. A complete botanical description is here provided for a discovered ancient rose. It is also characterised according to a series of sequence tagged microsatellite sites, and its agronomic features are reported. In addition, a histological description (optical and scanning electronic microscope studies) of the petals is offered, along with an analysis of the volatile compounds present in these organs as determined by solid phase microextraction and gas chromatography-mass spectroscopy. The results reveal the uniqueness of this ancient type of rose and suggest it may be of interest to the perfume industry.
\end{abstract}

\section{Introduction}

This work describes an ancient cultivated rose variety found growing in a private garden in western Asturias (northern Spain). Many wild roses grow in this area, but it was never thought to be home to ancient cultivated roses. The histological, genetic and biochemical analysis of the examined material reveal the uniqueness of this ancient variety-here named Narcea-and suggest it may be of interest to the perfume industry.

The first thing to understand when discussing roses is that wild roses-those found growing along paths and

Correspondence: María-Carmen Martínez (carmenmartinez@mbg.csic.es) ${ }^{1}$ Misión Biológica de Galicia (CSIC), Carballeira 8, Salcedo 36143 Pontevedra, Spain

${ }^{2}$ Instituto de Ciencia y Tecnología de Alimentos y Nutrición (CSIC) (Spain), C/José Antonio Novais 10, 28040 Madrid, Spain

Full list of author information is available at the end of the article tracks or in hedges lining meadows-are very different to cultivated roses. From a botanical standpoint, authors past and present coincide in describing the genus Rosa as one of the most complex and confusing, due to several factors including extensive hybridization and polyploidy. The genus Rosa can be divided into four subgenera ${ }^{1}-$ Hultemia (Dumort) Focke, Platyrhodon (Hurts) Rheder, Hesperhodos Cockerell, and Rosa Focke-which together include the 150 or so rose species distributed around the northern hemisphere. The first three of these subgenera have been little involved in the appearance of current garden roses and the subgenus Rosa includes nearly all cultivated rose species ${ }^{2}$.

In their wild state, roses are generally simple plants with a single row of petals and numerous stamens ${ }^{3}$. However, cultivation led to the appreciation that rose stamens can sometimes transform into petals. This led to the

\section{(c) The Author(s) 2020}

(c) Open Access This article is licensed under a Creative Commons Attribution 4.0 International License, which permits use, sharing, adaptation, distribution and reproduction cc) in any medium or format, as long as you give appropriate credit to the original author(s) and the source, provide a link to the Creative Commons license, and indicate if changes were made. The images or other third party material in this article are included in the article's Creative Commons license, unless indicated otherwise in a credit line to the material. If material is not included in the article's Creative Commons license and your intended use is not permitted by statutory regulation or exceeds the permitted use, you will need to obtain permission directly from the copyright holder. To view a copy of this license, visit http://creativecommons.org/licenses/by/4.0/. 
appearance of cultivated roses with numerous petals and very few (or no) stamens. According to the degree of transformation they have undergone, cultivated roses are classified in terms of their number of petals as single, semi double, or double. In the first half of the 19th century, authors ${ }^{3}$ reported there to be over 100 species of cultivated rose within the genus Rosa, all from the northern hemisphere and with none from further south than $25^{\circ} \mathrm{N}$. They also indicated that the cultivated roses of their time were rustic and abundant in southern Europe, and so numerous that many hybridisations are thought to have occurred (although in those days it was very hard to know the parent types involved or where they came from).

The great majority of the many ancient cultivated roses described in Europe in the 19th century ${ }^{3-7}$ have all but disappeared. All the latter authors, however, underscore Rosa centifolia (understood here to be a species, following the criteria of Koopman et al. ${ }^{8}$ ) as the rose par excellence. It was to this rose that was mostly grown in European gardens until species from China and India took its place (from 1867) ${ }^{3}$. Varieties of $R$. centifolia also provided the majority of the raw material used in the important 19th century rose essence industry. It was unsure whether $R$. centifolia was a native of southern Europe, although by this time it had certainly become naturalised in that part of the world, and in the form of different varieties ${ }^{3}$.

Another ancient rose commonly mentioned by all 19thcentury authors was $R$. gallica or the Provence rose. Authors ${ }^{3}$ described it as a different 'race' to R. centifolia, from which it was quite difficult to distinguish. The latter authors thought it unlikely that it arose as a hybrid of $R$. centifolia since it was so similar to it. However, the flowers of $R$. centifolia appear either alone or in groups of two or three, while the many varieties of $R$. gallica cultivated in the 19th century had flowers in groups of three or four, all growing from the same erect peduncle.

$R$. damascena was another ancient and much appreciated cultivated rose at the pass. This species, as well as $R$. centifolia and $R$. gallica, belongs to the subgenus Rosa $(2 \mathrm{x}=4 \mathrm{n})$ that has a mainly European genetically background $^{8} . R$. damascena is often treated as species in literature $^{8,9}$. Morphologically it can be distinguishable by its long thorns, oblong fruit, the way its flowers gather into a corymb, and the ease with which it could be propagated from cuttings ${ }^{3}$.

R. moschata Herrm., an ancient rose with origin in the Persian region or in the Eastern Mediterranean, was widely cultivated in the North of Africa during the XVIII century and was probably already known in Roman times ${ }^{10}$. This rose has been cultivated for centuries to obtain its essential oil ${ }^{10}$ which is currently used in many cosmetic products. This rose grows naturalised in several localities of the North of the Iberian Peninsula.
Nowadays, the majority of cultivated roses belong to the "Modern Roses" group, and were obtained from 1867 (the year when the French nurseryman Jean-Baptiste André Guillot introduced 'La France', the legendary first Hybrid Tea Rose) onwards via artificial crossings and improvement programmes. The aim was to achieve ornamental plants for gardens, and cut flowers. These roses usually have elegant, aesthetically attractive flowers, and there are thousands of colours and forms-but all have little fragrance. The so-called "Ancient Roses", all of which have now practically disappeared, are generally more rustic, more ungainly and less aesthetically pleasing. However, the roses of this group are those used in the making of perfume; the intense, exquisite fragrance produced by some varieties has never been reproduced in the laboratory.

Wild roses of different species are abundant in Spain, especially in the Aragonese Pyrenees ${ }^{11}$ and the west of Asturias (Supplementary Fig. S1) - the latter being home to perhaps some $75 \%$ of the species within the genus Ros $^{12-14}$. There is, however, but one dubious reference to the country ever having been home to a cultivated ancient rose. One Rosal Castellano de flor muy doble as belonging to $R$. gallica L. was mentioned, perhaps because of its Spanish name ${ }^{15}$. However, neither authors of this work ${ }^{14}$ nor anyone else mentions anything else about this variety, nor has a specimen confirming its existence been found.

For earlier authors, the characterisation and classification of cultivated roses was a complex business, due to their complex hybrid origin and polyploidy chromosomal series, but modern descriptive methods developed for the genus $\operatorname{Ros}^{11,16}$, allow now all researchers to use the same methodology and terminology. This makes the description and comparison of varieties much easier. Classification and taxonomy of genus Rose is still complex due to the existence of hybridation and different polyploid levels ${ }^{1}$. Molecular techniques ${ }^{17}$ are also available, and these techniques are being applied to detect genetic relationships ${ }^{8,9}$ or to answer specific questions about varietal identity that botanical techniques alone cannot. Among the molecular markers available, sequenced tagged microsatellite sites (STMSs) are regarded as neutral markers that are more informative when characterizing germplasm collections thanks to their abundance in eukaryotic genomes, their high levels of polymorphism, Mendelian inheritance, co-dominant nature, and locus specificity $^{17,18}$. STMSs markers have been widely employed in genetic diversity and mapping studies in rose ${ }^{9,17,19-21}$. Currently, thanks to next-generation sequencing, also single-nucleotide polymorphism (SNP) markers are available. They have lower information content per marker but automation makes possible to detect tens of thousands of markers simultaneously, resulting especially informative for allele dose determination ${ }^{22}$. 
With regard to roses used in perfume production, agronomic characteristics such as the number of roses per bush, the size of flowers, the number of petals each flower has, and the weight of the petals, are also of interest (the essential oils used in perfumery are extracted from the petals). Knowledge of the histological characteristics of the petals is also important since it is in the petal tissues where these oils are stored. The content and concentration of the volatile compounds present in the essential oil determines the aromatic profile of a rose variety, and bears strongly on its importance to the perfume industry. Indeed, great varietal differences exist ${ }^{23,24}$ in terms of the characteristics, quality, intensity and persistence of a rose aroma. The final aroma is a product of the varying presence of citronelol, geraniol, nerol, linalool, phenylacetic alcohol and other compounds, which can be affected by the time when the petals are collected, soil type, climate, and cultivation practices ${ }^{25-27}$.

The aim of the present work was to botanically, genetically, histologically and biochemically characterise an unknown ancient, cultivated rose variety discovered in northern Spain, and to provide preliminary data of possible interest to the perfume industry. Should it generate such interest, it would be the first variety from Spain, and as far as we know only the third from Europe, to do so.

\section{Materials and methods}

Plant material and climate of the area where it was found

The examined plant material is from a very old, cultivated, domesticated type of rose found growing in the private garden of a house in the small village of Carballo (Concejo de Cangas del Narcea, in the Principality of Asturias, northern Spain), which nestles in the valley of the River Cibea. Several specimens of this type of rosebush may have been growing in this same garden before 1867 (and possibly before 1832) (personal communications from local inhabitants). Certainly, their long existence was known to several senior villagers. Their large roses with their many petals, notable colour and agreeable aroma, led to their being collected for use in the festival of Corpus Christi, the petals being thrown into the air as the religious procession passed by. Indeed, even if the flowering of the rose depends on temperature and humidity conditions, we could approximately predict flowering time thanks to the fact that the oral tradition had stablished that flowering occurred around the time of this festival (which falls on the ninth Sunday after the first spring full moon in the northern hemisphere). Today there are three such plants in the same garden; these are now being used to propagate more specimens.

Carballo lies in a mountainous area (with altitudes rising from 300 to $1700 \mathrm{~m}$ over just a few kilometres) that forms part of the Cantabrian Mountain Range, where there are many rivers with steep-sided valleys. Coastal humidity is held back by these mountains. Together these factors confer upon the area its particular microclimate, the details of which are provided in Supplementary Table S1 (data collected by an iMetos 2 agroclimate station present in Carballo since 2010).

\section{Botanical characterisation and data of agronomic interest}

Plant characteristics were recorded over the growth cycle, collecting data on the features of the shoots, adult leaves, flowers and fruits. The flowers were inspected on 31st May 2018 (10 flowers collected from each of the three bushes). A botanical description was made following the protocol of the International Union for the Protection of New Varieties of Plants ${ }^{15}$ for the genus Rosa, as well as the descriptive method of Monserrat et al. ${ }^{10}$. Drawings and photographs of different plant organs were made. On the same 31st May, the number of flower buds, and the number of open roses per plant was recorded.

Between five and eight further roses were collected from each plant, and the number of petals per flower, the weight of the petals per flower and the weight of each petal recorded before freezing them at $-30{ }^{\circ} \mathrm{C}$ until further analysis.

\section{Molecular characterisation DNA extraction}

Fresh leaves were collected in April 2018 and stored at $-80^{\circ} \mathrm{C}$ for DNA extraction. Using a pestle and mortar, leaf material $(0.2 \mathrm{~g})$ was homogenised in $1 \mathrm{~mL}$ of $\mathrm{CTAB}$ buffer, as described by De la Rosa et al. ${ }^{28}$. DNA was then extracted using the Maxwell ${ }^{\circ}$ PureFood Kit and Maxwell RSC Instrument (Promega Corporation, Madison, WI, USA) following the manufacture's recommendations. The extracted DNA was resuspended in $100 \mu \mathrm{L}$ of elution buffer (provided with the kit), and quantified using a Biodrop LLITE $^{\circ}$ spectrophotometer (BioDrop, Cambridge, UK). DNAs extracted from the roses 'Belle de Crécy', 'Jolande d'Aragone', and 'Alain Blanchard' (Scariot et al. $^{17}$ ) were used as reference for further analyses.

\section{STMS amplification}

STMSs were amplified by PCR in a $20 \mu \mathrm{L}$ reaction volume containing $2 \mu \mathrm{L}$ 10X PCR buffer $(100 \mathrm{mM}$ TrisHCL, pH 8.3, $500 \mathrm{mM} \mathrm{KCl),} 1.5 \mathrm{mM} \mathrm{MgCl}_{2}, 0.5 \mu \mathrm{M}$ of each primer, $200 \mu \mathrm{M}$ dNTP, $0.5 \mathrm{U}$ taq-DNA polymerase (i.e., AmpliTaq Gold DNA polymerase [Applied Biosystems, Foster City, CA, USA]) and 50 ng of template DNA. Amplifications were performed in a PTC 100 thermocycler (MJ Research, Watertown MA, USA). The primers used, developed by Esselink et al. ${ }^{29}$, were RhAB22, RhE2b, $\mathrm{RhD} 221, \mathrm{RhO} 517$, and RhP519. The forward primers were labelled with a fluorochome (6-FAM, HEX or NED). Amplification cycles consisted of an initial step of $11 \mathrm{~min}$ at $95^{\circ} \mathrm{C}$, followed by 26 cycles of $30 \mathrm{~s}$ at $95^{\circ} \mathrm{C}, 40 \mathrm{~s}$ at 
$55^{\circ} \mathrm{C}, 1 \mathrm{~min} 30 \mathrm{~s}$ at $72^{\circ} \mathrm{C}$, with a final extension step of 45 min at $72^{\circ} \mathrm{C}$.

\section{Detection of STMS polymorphism}

One microlitre of a mix containing amplification products of three differently labelled loci was added to $3 \mu \mathrm{L}$ of a mix containing 10:2:1 parts formamide, GeneScan350ROX size standard (Applied Biosystems) and a loading buffer ( $25 \mathrm{mM}$ EDTA, $50 \mathrm{mg} \mathrm{mL}^{-1}$ blue dextran). Fluorescent samples were denatured at $95^{\circ} \mathrm{C}$ for $5 \mathrm{~min}$ and the DNA fragments separated on a sequencing gel $(4.25 \%$ acrylamide, $1 \mathrm{X}$ TBE buffer, $6 \mathrm{M}$ urea) using an ABIPRISM 377 DNA sequencer running GeneScan software (Applied Biosystems).

\section{Data analysis}

The obtained STMS peaks were scored as discrete variables (namely allelic phenotype), using 1 or 0 to indicate the presence or the absence of each fragment. Data were compared with the original dataset reported by Scariot et al. ${ }^{17}$, made available by the authors. The genetic distance between pairs of accessions was estimated on the basis of the Nei coefficient and a principal coordinate analysis (PCA) was conducted using GeneAlEx $6.3^{30}$.

\section{Histological characterisation of the petals}

Several petals from each of the three rosebushes were thawed to room temperature and fixed in FAA $\left(90 \% 70^{\circ}\right.$ ethanol, $5 \%$ glacial acetic acid, $5 \%$ formaldehyde) for $48 \mathrm{~h}$. They were then transferred to $70^{\circ}$ alcohol, passed through a dehydrating series of ethanol solutions (using isoamyl acetate as an intermediary liquid) and set in paraplast blocks. These were cut using a $12 \mu \mathrm{m}$ microtome and deposited on microscope slides. Some preparations were stained with safranin and fast green (before being immersed in xylene to remove the paraffin), mounted in Entellan, and examined using a Nikon E600 microscope (bright field, polarized light and epifluorescence microscopy).

For histochemical detection of lipids, small fragments of petals were fixed for $24 \mathrm{~h}$ in $4 \%$ paraformaldehyde in $0.1 \mathrm{M}$ phosphate buffer (PB). The samples were rinsed with the same buffer and cryoprotected by passing through sucrose solutions in increasing concentration (10, 20 , and $30 \%)$. Sections ( $12 \mu \mathrm{m}$ thick) were obtained in a cryostat and collected on gelatin-coated slides. The stain was performed with the Sudan III technique following the standard method described in Kiernan ${ }^{31}$. The sections were examined with an Olympus BX51 microscope and photographed with an Olympus DP71 digital camera.

Fragments of the fixed petals were also passed through a dehydrating series of ethanol solutions and after critical point drying were gold-covered and examined using a FEI Quanta 600 environmental scanning electron microscope (ESEM).

\section{Analysis of petal volatile compounds}

Six to eight more flowers from each of the three rosebushes were collected, their petals separated, weighed and stored separately (by bush) at $-80^{\circ} \mathrm{C}$. A portion of those from each bush-Bush $1=30.46 \mathrm{~g}$; Bush $2=38.33 \mathrm{~g}$; Bush $3=39.90 \mathrm{~g}$-was lyophilised using a Gamma 2-16 LSCplus lyophilising device (CHRIST, Osterode am Harz, Germany) at 0.10 mbars (lyophilised Bush $1=3.4 \mathrm{~g}$; lyophilised Bush $2=4.67 \mathrm{~g}$; lyophilised Bush $3=3.29 \mathrm{~g}$ ) and sent for volatile compound analysis at the Instituto de Ciencia y Tecnología de los Alimentos y Nutrición-CSIC (Madrid, Spain).

The volatile compound profile of the essential oil of a Damask rose of French origin (Rose absolute, Moroccan, Ref.W298816-Sample-K) was examined as a reference against which to compare the studied petals. Samples for analysis were prepared in duplicate on the same day and maintained refrigerated until use. Samples of $0.05 \mathrm{~g}$ of each petal sample, or $20 \mu \mathrm{l}$ of the Damask oil, were placed in a $20 \mathrm{~mL}$ glass headspace vial with a silicon/PTFE septum screw cap. Analyses were undertaken over two days, using one of the replicates each day, employing divinylbenzene/carboxen fibres (Ref. 57328-U Supelco [Merck KGaA, Darmstadt, Germany]). The volatile compounds of each were extracted by solid phase microextraction (SPME) and analysed by GC-MS (CG: Agilent 6890N device [Agilent Technologies, Santa Clara, CA, USA]; MS: 5973 device [Agilent Technologies, Santa Clara, CA, USA]) running MSD Chemstation software.

The technical details for CG-MS included equilibration of the heating plate at $50^{\circ} \mathrm{C}$ for $30 \mathrm{~min}$ and $50{ }^{\circ} \mathrm{C}$ for 15 min extraction with the fibe; desorption of the injector at $240{ }^{\circ} \mathrm{C}$ for $15 \mathrm{~min}$; volatile compounds column DBWAXetr (polyethylene glycol $60 \mathrm{~m}, 320 \times 0.25 \mu \mathrm{m}$ ); carrying gas - helium, constant flow $(1.3 \mathrm{~mL} / \mathrm{min})$; Injection desorption SPME splitless, $240^{\circ} \mathrm{C}$; heating gradient $-40^{\circ} \mathrm{C}$ $4 \min , 4^{\circ} \mathrm{C} / \min 110^{\circ} \mathrm{C}, 6^{\circ} \mathrm{C} / \min 180^{\circ} \mathrm{C}, 8^{\circ} \mathrm{C} / \min 240^{\circ} \mathrm{C}$ $15 \mathrm{~min}$; auxiliary temperature $250^{\circ} \mathrm{C}$, detector temperature $230^{\circ} \mathrm{C}$; mass range $(\mathrm{m} / \mathrm{z})-27-450$; data treatment: MassHunter Qualitative Analysis B.07.00 software.

Compounds were identified by comparison against the spectra in the Wiley Registry 7th Edition Spectral Library and the National Institute of Standards and Technology 2008 Mass Spectral Library (NIST 08), and by calculating linear retention indices with respect to a series of alkanes (C6-C20).

\section{Results}

Botanical characterisation and data of agronomic interest

The following is a description of the examined rosebushes according to the descriptive method of Montserrat el al. ${ }^{11}$ (Figs. 1 and 2). Bush with strong, erect stems, 2-3 $\mathrm{m}$ long. Thorns are very dispersed, yellowish, triangular (isosceles) becoming quickly wider towards the base; 
point straight or slightly curved. Thorns interspersed by numerous straight, narrow spines. Leaves $10-13 \times$ $8.5-11 \mathrm{~cm}$, with 5 leaflets (sometimes three at the base of the inflorescence) of $5 \times 3.5-4 \mathrm{~cm}$ (the terminal leaflet is larger with a longer point, sharp or slightly acuminate), thick, ovate, coriaceous, upper and lower surfaces glabrous, discoloured with a few sessile glands on the rachis; denticulation not deep, crenated, almost simple without glands. Stipules long and narrow $(2.5 \times 0.2 \mathrm{~cm})$, concrescent with peciole and with two pointy lobules, divergent, nearly $1 \mathrm{~cm}$ in length, hairy and with pectin glands along the margin. Inflorescence with one,

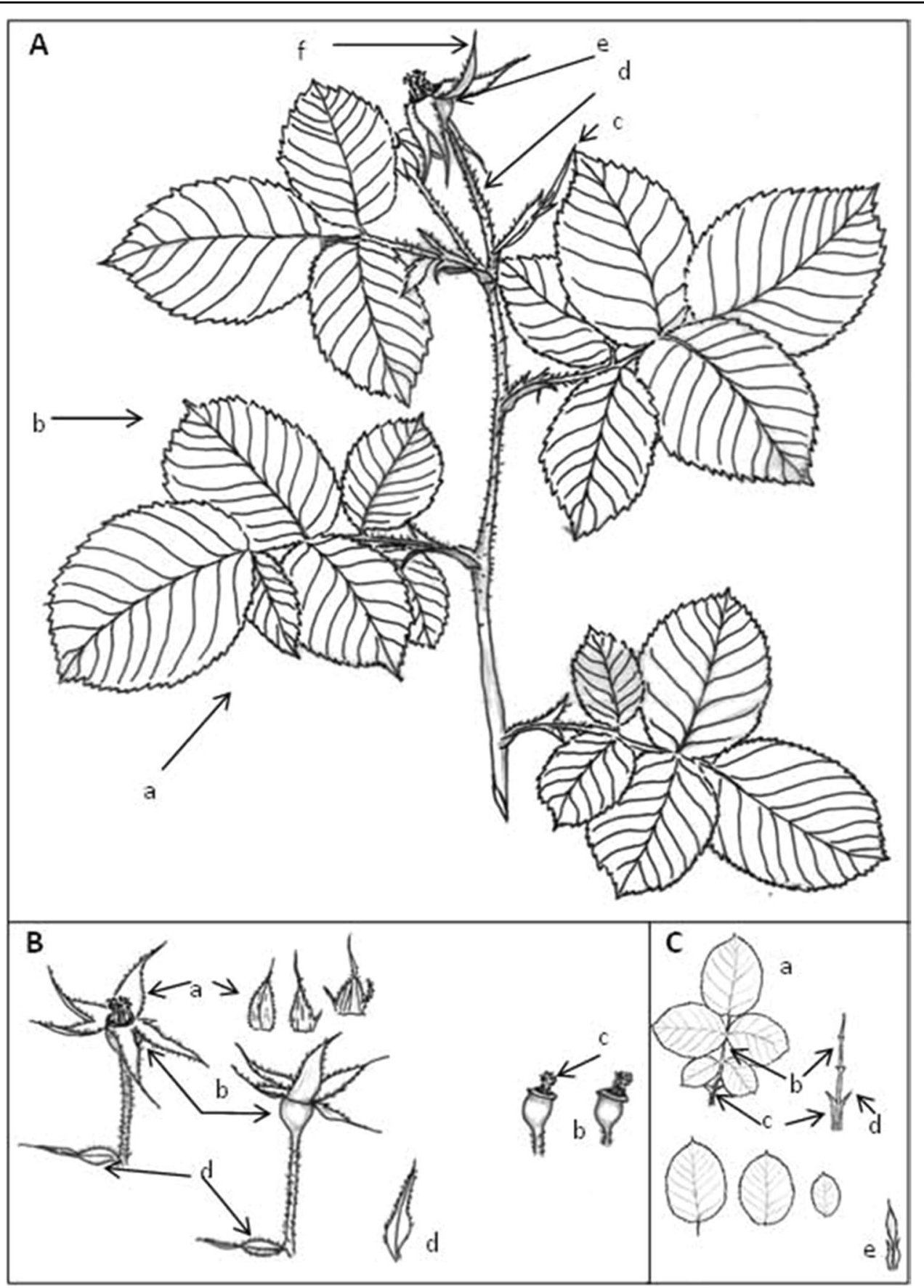

Fig. 1 Details of different parts of the leaves and flowers of the Narcea variety. a Inflorescence with leaves (a) folioles (b) bract (c) pedicel (d) hypanthium (e), sepals (f). (b) (a) sepals (b) hypanthium (c) stamens (d) bract. (c) Folioles (a) united by a central vein or rachis (b) at the base of which are stipules (c) fused to the peciole except on the upper part or auricle (d). Left. bract (e) of the flower 

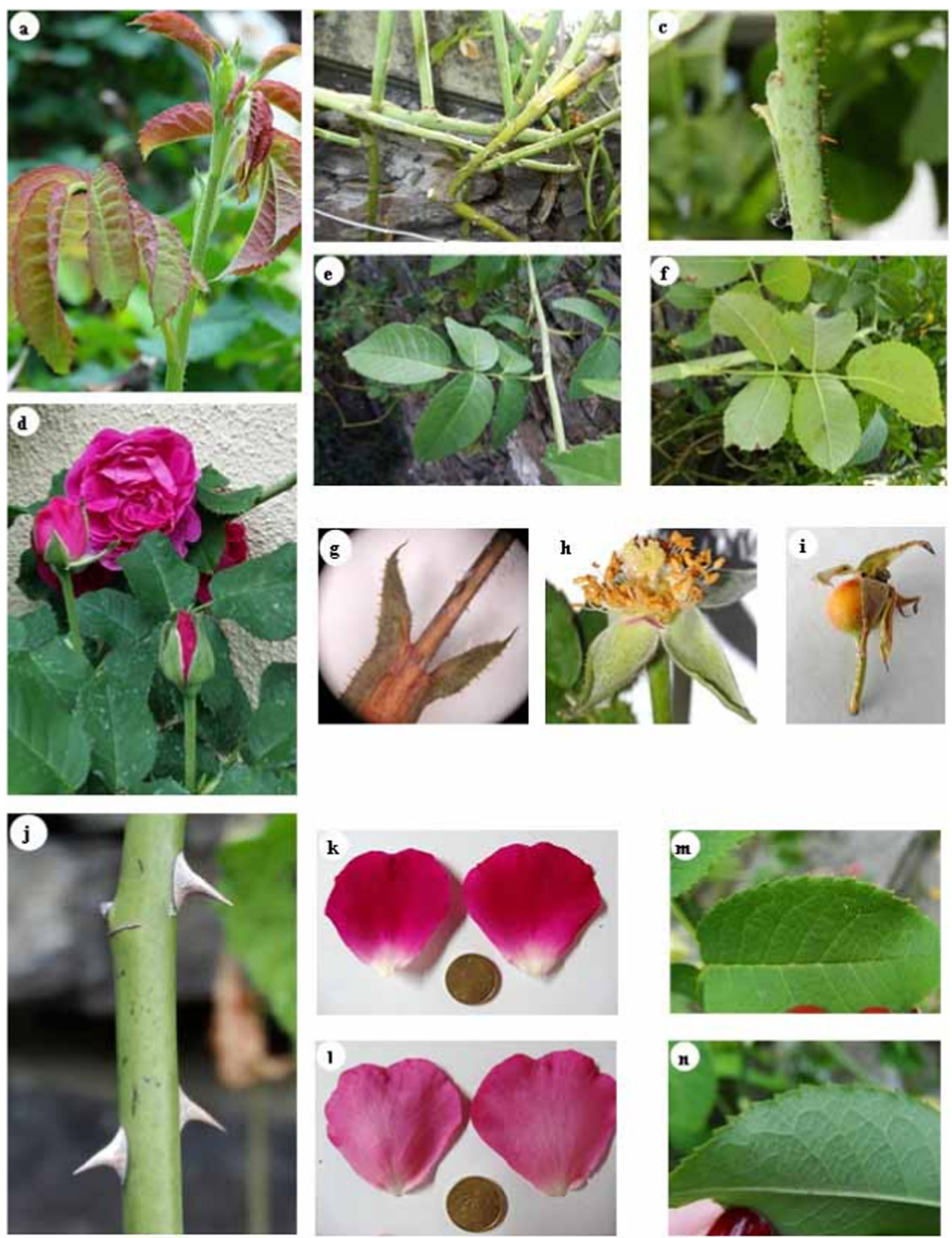

Fig. 2 Details of different organs of the Narcea variety. Shoot with copper-coloured leaves (a), dispersed thorns (b), narrow, straight spines (c), "double" roses with purplish-red flowers (d), leaves with 5 folioles, upper surface $(\mathbf{e})$, lower surface $(\mathbf{f})$, stipule $(\mathbf{g})$, stamens and pistil (h), false fruit or rose hip (i), upper side of petal $(\mathbf{k})$, lower side of petal $(\mathbf{i})$, upper side foliole $(\mathbf{m})$, lower side foliole $(\mathbf{n})$. Reference: $10 €$ cent coin 
sometimes a few, large $(8 \mathrm{~cm}$ diameter $)$ fragrant flowers with very fallen bracts and a long pedicel $(2-3 \mathrm{~cm})$, thorncovered and glandular. Petals purplish-red, styles free but generally grouped into a column that does not pass beyond the line of the stamens. Stylar disc a little concave, $6.70 \mathrm{~mm}$ in diameter with a pore $2.95 \mathrm{~mm}$ in diameter; the disc size is therefore large and the pore size small (33-50\% of the disc size). Sepals triangular, prolonged, with an apical lobule, hardly any lateral projections, reflexing and persistent during fruiting, dorsal and lobules glandulous. Fruit subglobous or slightly urceolate, a little over $1.2 \mathrm{~cm}$ long and $1.1 \mathrm{~cm}$ wide at the broadest point.

The flowers are very attractive given their intense fragrance and the homogenous purplish-red colour of their many medium-large sized petals (those at the centre are smaller) (Supplementary Fig. S2).

Supplementary Table S2 shows the full botanical characterisation results according to the International Union for the Protection of New Varieties of Plants ${ }^{15}$ protocol. Supplementary Table S3 relates the botanic features of agronomic interest.

\section{Molecular characterisation}

Microsatellite profiles of Narcea rose and reference genotypes ('Belle de Crécy', 'Jolande d'Aragone', and 'Alain Blanchard') were examined and compared with those of 44 ancient garden roses representative of the main horticultural groups (3 Alba, 3 Hybrid China, 3 Noisette, 4 Tea, 5 Bourbon, 4 Centifolia, 2 Damask, 8 Gallica, 2 Hybrid Perpetual, 3 Moss, and 7 Portland), previously obtained by Scariot et al. $(2006)^{17}$.

The genetic relationships are illustrated via PCA scatter plots (Fig. 3). The first two coordinates in Fig. 3a account for 21.09 and $11.19 \%$ of the variance. With high first axis values, the examined material fell between the rose groups Centifolia, Gallica, Moss, and Portland. An in-depth analysis was therefore performed to better understand the relationships between the examined material and the latter groups. Figure $3 \mathrm{~b}$ shows the examined material to cluster within the Gallica group, and to be particularly close to the cultivar 'Belle de Crécy' and 'Jenny Duval' whose allele sizes are reported in Table 1.

\section{Histological characterisation of the petals}

Figure 4 shows (from the adaxial to the abaxial face of the leaf) the different parts of the studied petals mesophyll. The adaxial epidermis is formed by a single layer of papilliform cells (Fig. 4a-c). These papillae afford the epidermis a granular appearance (Fig. 4d). Cuticular striations converge towards the apex of these papillae (Fig. 4e). Lipids were visible in the spaces between the papillae and on these striations (Fig. 4h). The storage parenchyma shows abundant, large intercellular spaces (Fig. $4 \mathrm{a}-\mathrm{c}$ ) with no crystalline inclusions. Small collateral vascular bundles are also visible (Fig. 4a, b).

The abaxial epidermis is a single layer of flat cells (Fig. 4a, b). The cuticle has striations that do not mark the edges of cells (Fig. 4f, g); these striations contain lipids (Fig. 4i).

\section{Petal volatile compounds}

Supplementary Table S4 shows the volatile compounds identified, ordered by family and indicating the retention times (RT), the calculated linear retention indices (LRIc), and the same index as recorded in the available libraries NIST 08 and Wiley (LRIl). Supplementary Table S5 and Fig. 5 show the quantities of different compounds detected in the examined petals (expressed as a percentage of the total compounds detected) compared to the profile of the commercial rose essential oil. These results do not preclude the presence of other, minor compounds. The values in Supplementary Table S5 are the means of the two measurements made for each petal analysed, and in the case of the oil, of the duplicate analysis.

\section{Discussion}

The present results show the examined material to belong to an unknown, ancient cultivated variety of rose, for which the name Narcea is here proposed in honour of the geographical area of the Principality of Asturias (northern Spain) where the rose was discovered.

Both the botanical description undertaken following the method of Montserrat et al. ${ }^{11}$, and of the International Union for the Protection of New Varieties of Plants ${ }^{16}$, showed the studied material to have characteristics common to both R. gallica and R. centifolia (as described by Decaisne and Naudin $^{3}$ ), including its intense aroma, the presence of glandulous hairs, and leaves with five folioles. It also had some characteristics exclusive to $R$. gallica, such as inflorescences formed by a single (or sometimes a few) erect, purplish-red aromatic flowers, and styles with yellowish hairs grouped into a column. Note that $R$. centifolia has hanging flowers, with clear pink petals, and the calyx tube has reddish hairs.

The studied material was also similar to $R$. gallica in terms of its little-concave disc, the presence of triangular, reflexing sepals with hardly any lateral projections, and with a globous dorsal side and lobules, as well as the subglobous form of the fruit.

Supplementary Table S3 shows the examined material's features of agronomic interest. The mean number of open roses for the three bushes was 37.33, although the coefficient of variation was large (as determined on 31st May). The number of closed buds on each bush was even more variable (between 11 and 130). This variation might be explained by the fact that one of the bushes was planted in 


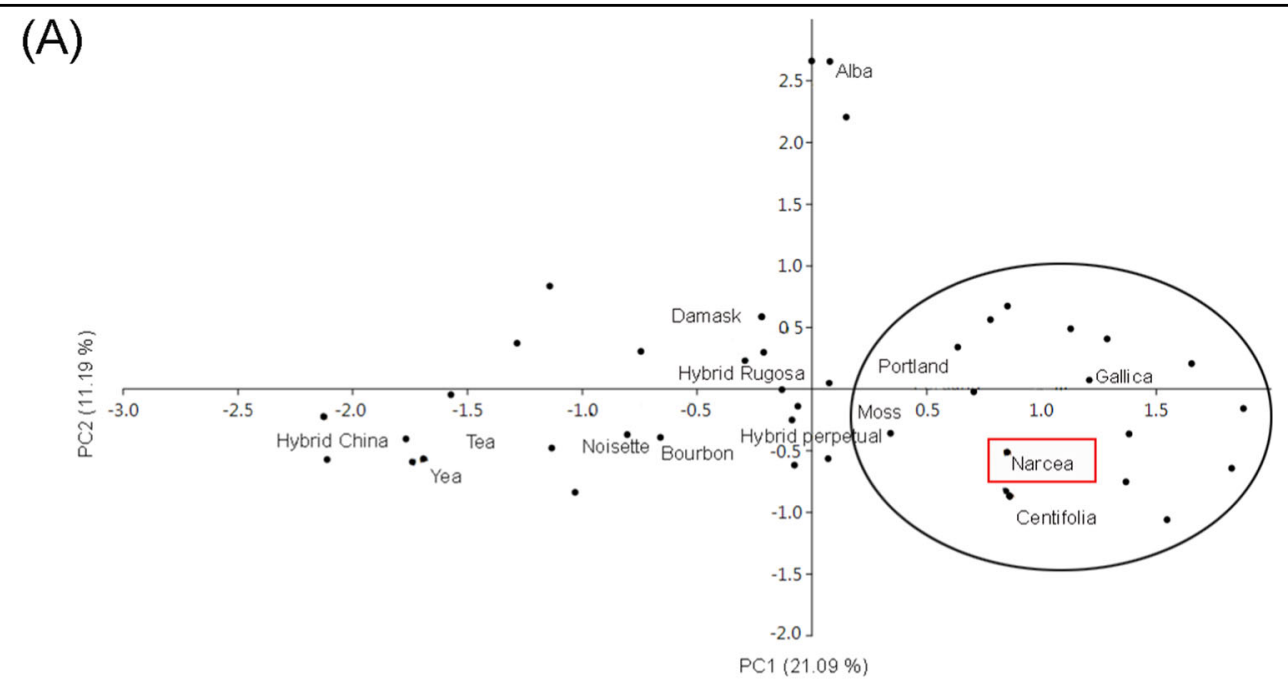

(B)

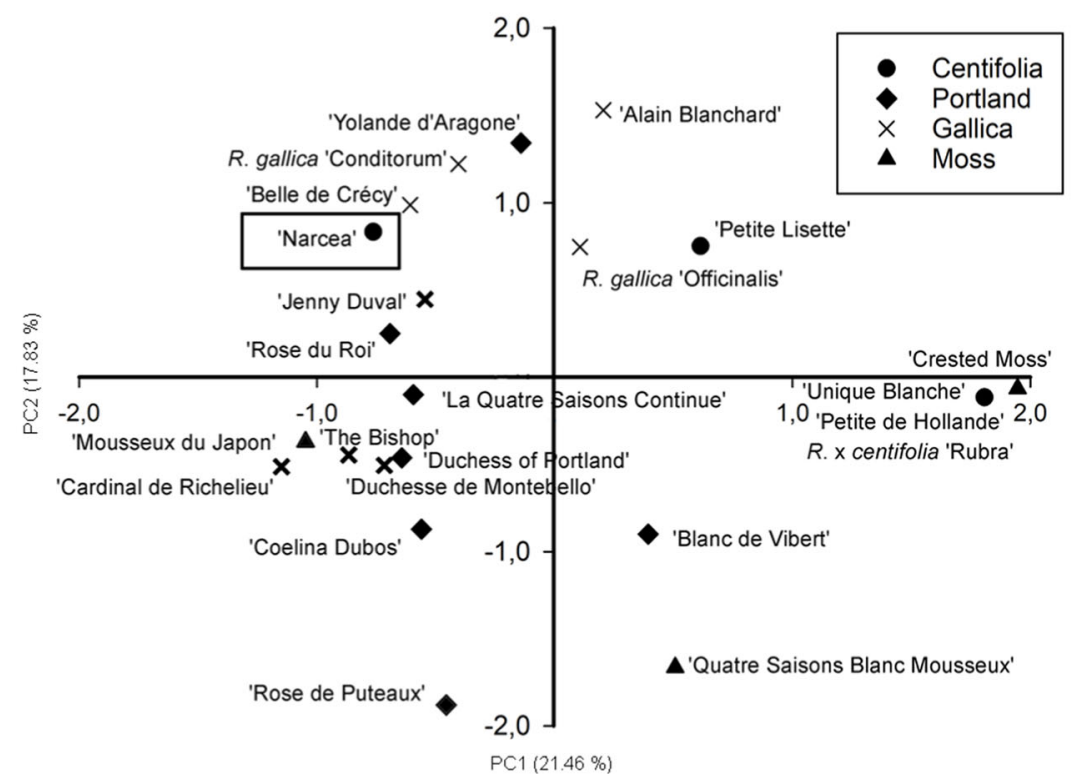

Fig. 3 a Principal coordinates analysis scatter diagram for the Narcea and rose horticultural group (Scariot et al. $)^{17}$ : STMSs data. b. Principal coordinates analysis scatter diagram for the Narcea and rose cultivars belonging to the horticultural groups Gallica, Centifolia, Moss and Portland (Scariot et al.). ${ }^{17}:$ STMSs data

the ground and the other two in large pots, which could have influenced their vigour and therefore the number of buds and open flowers produced. For more reliable data regarding these variables, studies on larger numbers of bushes of the same age would be required, with all subjected to the same cultivation practices. Both, the total number of petals and the flower weight are higher in Rosa Narcea than in $R$. damascena and $R$. centifolia ${ }^{32,33}$. Also, the mean petal weight of $10.43 \mathrm{~g} /$ rose was rather constant. Thus, being in the ground or in a pot seems to influence the number of flowers produced, but not the weight of the petals of those flowers-a character apparently more strongly related to varietal identity than the conditions under which plants grow. The mean number of petals per
Table 1 Allele sizes (bp) of the STMS markers used to characterize the unknown ancient cultivated rose variety (Narcea), 'Belle de Crécy', and 'Jenny Duval' as reported by Scariot et al. ${ }^{17}$

Allele sizes (bp)

\begin{tabular}{llll}
\hline STMS locus & 'Narcea' & 'Belle de Crécy' & 'Jenny Duval' \\
\hline RhAB22 & 165,169 & 165,169 & 165 \\
RhD221 & $206,217,220,223$ & 220 & 206,220 \\
RhE2b & $179,185,189$ & $173,182,185$ & 176,185 \\
RhO517 & $251,254,257,260$ & 257,260 & $254,257,260$ \\
RhP519 & $217,229,235$ & $217,229,238$ & 217,229 \\
\hline
\end{tabular}



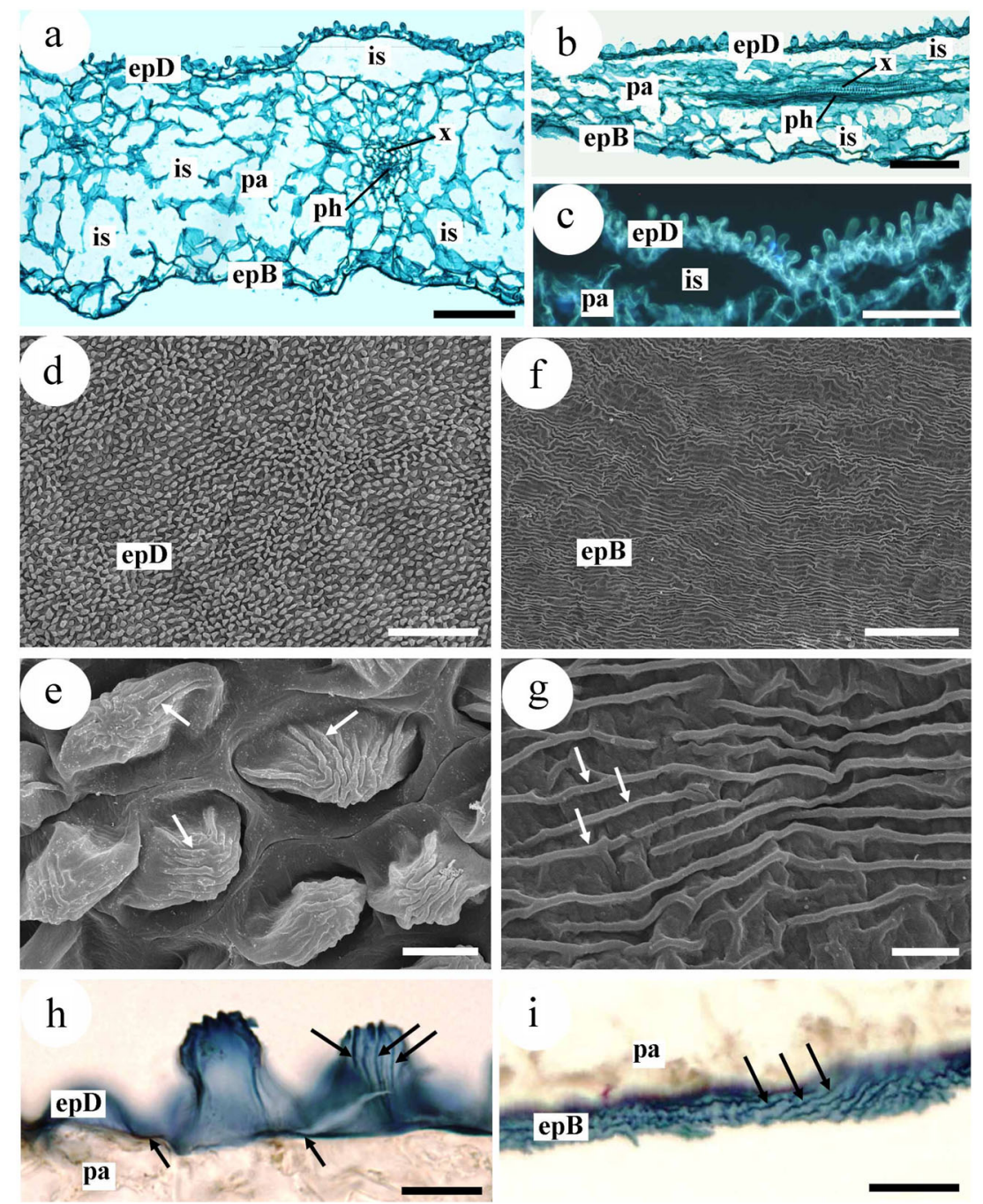

Fig. 4 Histological study of a Narcea rose petal. a Transverse section of the petal. Between the adaxial (epD) and abaxial epidermises (epB) lies storage parenchyma (pa) with many intracellular spaces (is). Notice also xylem ( $\mathrm{x}$ ) and phloem (ph) making up a small, collateral vascular bundle. Note also the papillae on the adaxial epidermal cells. $\mathbf{b}$ Longitudinal section of the lamina. $\mathbf{c}$ Detail of the adaxial epidermis (epD) with papilliform cells of the adaxial surface. $\mathbf{d}$ Abundant promontories corresponding to the papillae of the epidermal cells. e Detail of ' $\mathbf{d}$ '. The arrows mark striations in the cuticle of the epidermal cells. $\mathbf{f}-\mathbf{g}$ Surface of abaxial epidermis. $\mathbf{f}$ Note the epidermal cells are not papilliform. $\mathbf{g}$ Detail of latter. Arrows mark cuticular striations. $\mathbf{h}$, $\mathbf{i}$ Detection of lipids. $\mathbf{h}$ Lipids (arrows) in the adaxial epidermis (epD), in fact in the cuticular striations and the spaces between the papillae. $\mathbf{i}$ Lipids (arrows) in the striations of the abaxial epidermis (epB). $\mathbf{a}, \mathbf{b}$ safranin and fast green. $\mathbf{h}, \mathbf{i}$ Sudan III. a, b h, i Optical microscopy, bright field. $\mathbf{c}$ Epifluorescence microscopy. $\mathbf{d}-\mathbf{g}$ Scanning electron microscopy. epB epidermis abaxial, epD epidermis adaxial, is intercellular space, $p a$ storage parenchyma, ph phloem, $x$ xylem. Bars: $\mathbf{a}-\mathrm{c}=100 \mu \mathrm{m}, \mathbf{d}=200 \mu \mathrm{m}, \mathbf{e}=10 \mu \mathrm{m}, \mathbf{f}=50 \mu \mathrm{m}, \mathbf{g}=5 \mu \mathrm{m}, \mathbf{h}, \mathbf{i}=20 \mu \mathrm{m}$

rose was also similar across the bushes (around 62 petals per rose). The mean petal weight per flower was $0.26 \mathrm{~g}$, but in this case the coefficient of variation was larger. Indeed, Fig. 4 shows that the petals were not all of the same size, with the three of four at the centre surrounding the reproductive organs much smaller than the rest.

The results of the STMS analysis (Table 1 and Fig. 3) show that Narcea most likely is a tetraploid genotype as well as $R$. x centifolia and $R$. gallica ${ }^{34}$ and is genetically close to the Gallica cultivars 'Belle de Crécy' and 'Jenny Duval', with unknown parents. Many modern roses are also tetraploids ${ }^{9,21}$ and all the essential oil Rosa species/ cultivars are tetraploid $(2 n=4 \times=28)$, providing better chance for successful crosses ${ }^{35}$.

The examined petals had the same general histological features of all petals of the genus $\operatorname{Ros}^{36-39}$, e.g., an adaxial epidermis with papilliform cells, an abaxial epidermis in which these cells are absent, with both epidermises showing striations, and the storage parenchyma with abundant spaces.

The histochemical location of the lipids in the epidermis, and their absence in the intercellular spaces may 


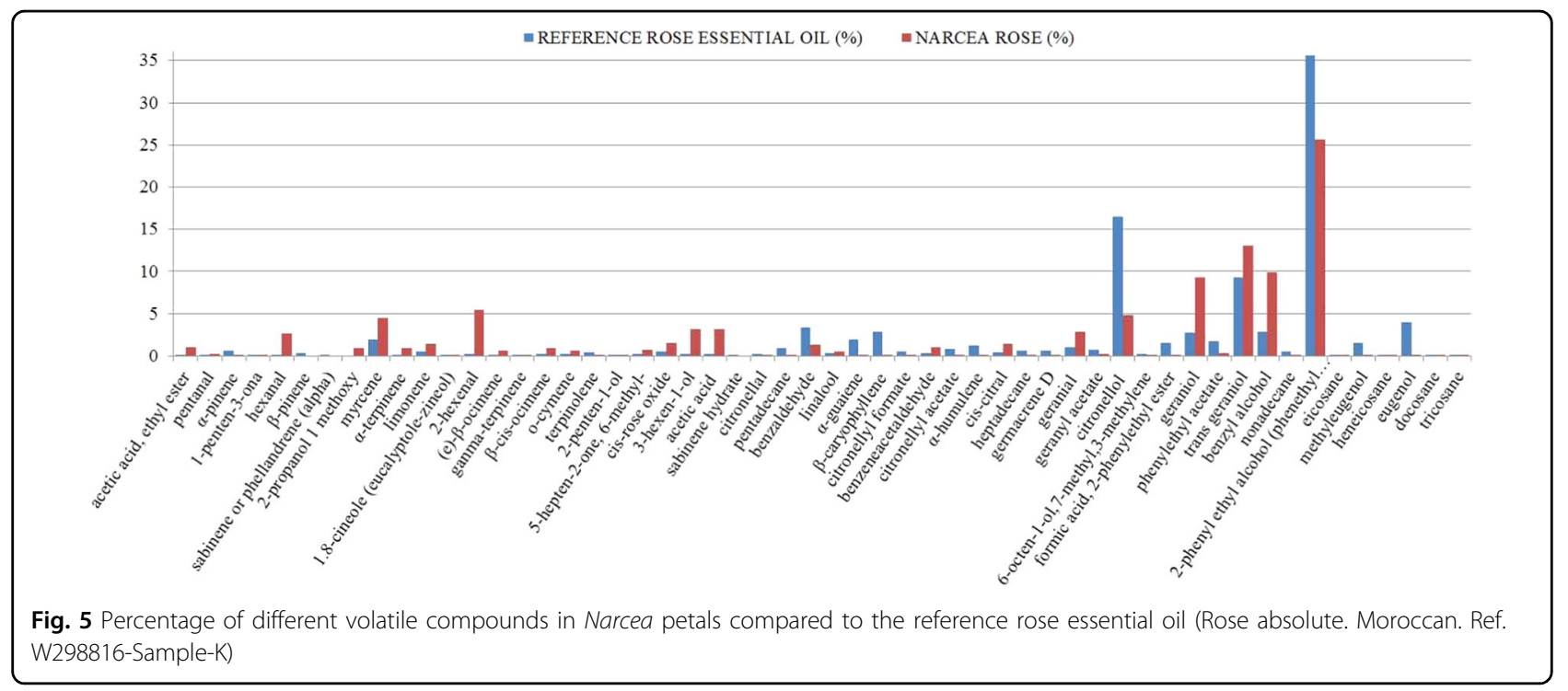

reflect the functional moment of the petal. Petals mostly emit their fragrance when the flower is fully open ${ }^{37}$; this is when the intercellular space contains droplets of essential oil $^{39}$. However, if oil does not enter the intercellular spaces until a certain time of day, say the afternoon or evening, this would explain its absence in the examined petals (the flowers were picked in the morning). The molecules that provide the characteristic smell are released to the exterior via the cuticle ${ }^{37,40}$; certainly, oils were detected in the cuticles of both epidermises.

Figure 5 and Supplementary Table S5 show the concentrations of volatile compounds detected in the petals. Compounds such as nonadecane, methyleugenol, heneicosane and tricosane, which reduce the quality of rose essential oil ${ }^{27,41}$ were absent or in very small quantities in the examined material. The examined material contained a number of compounds of great interest in perfume and rose essential oil production, such as hexanal, myrcene, $\alpha-$ terpinene, limonene, 2 -hexenal, (e)- $\beta$-ocimene, $\beta$-cis-ocimene, o-ocymene, 5-hepten-2-one, 6-methyl-, cis-rose oxide, 3-hexen-1-ol, cis-citral (-neral or 2,6-octadienal, 3,7-dimethyl), and especially geranial (alpha-citral or trans), geraniol, trans geraniol and benzyl alcohol.

The key aroma compounds of rose based products are $\beta$-phenylethyl alcohol, citronellol, geraniol, eugenol, linalool and rose oxide ${ }^{40}$, and all are present in the petals from Narcea Rose. The compounds cis-rose oxide, ciscitral, geranial, geraniol and trans geraniol, which are found in high quality oil ${ }^{27,41}$, were present in large amounts in the examined petals. However, citronellol appeared in lower proportion than in the reference essential oil. Cis-rose oxide, cis-citral, geranial, geraniol, tras geraniol and citronellol together confer cut grass-type aromas to different types of fruit (e.g., green apple), jasmine flowers and rose flowers. Their varying presence and proportion in different rose essential oils determines their character and quality. Other components derivatives of monoterpene alcohols as Citronellyl formate, citronellyl acetate, geranyl acetate and neryl acetate are, which made the aroma more harmonious $^{24}$ are also present in the examined petals.

It should be remembered that a rose's aroma is not the product of a single compound but a complex mixture of compounds, some of which may be present in tiny amounts $^{42}$. It is precisely this complexity that makes it so hard to synthesise an alternative in the laboratory. Rose essential oil - the most expensive of all plant essential oils -has, therefore, to be made from rose petals. Obtaining one litre of $R$. damascena or $R$. centifolia oil may require 3-4 tons of petals ${ }^{26}$, all of which need to be picked over a single, relatively short flowering period (end May-early June), explaining why that litre may fetch $€ 14,000$. Fortunately, only tiny quantities are needed to produce much larger volumes of perfume and other cosmetics. The discovery of the Narcea variety may, therefore, have an important economic dimension as there is need to develop the new varieties of oil-bearing roses by maintaining the standards of scent molecules of rose oil. But among all Rosa species, about $20 \%$ species are considered as scented, $50 \%$ are low scented and the rest are nonscented $^{35}$ and there are a lot of steps required creating a new cultivar from traditional crosses ${ }^{35}$. Flower morphology and scent composition of the Narcea Rose show that this particular rose has an important breeding potential.

The variety may also be of pharmacological, medical and food interest. Certainly, ancient cultures used roses for the treatment of many physical and mental problems $^{43-47}$, and in recent years interest has developed in understanding the true medical and food-value properties of these plants ${ }^{48,49}$. Further work is needed to determine whether this is the case. 


\section{Conclusions}

The present results show the discovered rosebushes to belong to an unknown, ancient cultivated variety, for which the name Narcea is proposed. A complete description is provided of the first reliably recorded ancient, cultivated rose from Spain. The present work is the first step required for the variety's protection and official recognition as a new, Spanish genetic resource. Some of the results suggest the variety may be of interest to the perfume industry. More work is needed to determine the best way to cultivate this variety and to further explore its agricultural and industrial potential.

\section{Acknowledgements}

The authors thank the House of Don Juan family (Carballo-Cangas del NarceaAsturias), which for more than seven generations has conserved and cared for the ancient rosebushes described. Thanks are also owed to Fernando, Lucía and Pilar of the House of Don Juan for providing diaries regarding the behaviour of the rosebushes over their growth cycle, to E. Zubiaurre and I. González for technical assistance, and to A. Burton (www.physicalevidence.es), for preparing the English version of this article. Part of this work has been developed in the framework of the CSIC Interdisciplinary Thematic Platform ALCINDER

\begin{abstract}
Author details
'Misión Biológica de Galicia (CSIC), Carballeira 8, Salcedo 36143 Pontevedra, Spain. ${ }^{2}$ Instituto de Ciencia y Tecnología de Alimentos y Nutrición (CSIC) (Spain), C/José Antonio Novais 10, 28040 Madrid, Spain. ${ }^{3}$ Departamento de Biología Molecular-Área de Biología Celular, Universidad de León, Campus de Vegazana s/n, 24071 León, Spain. ${ }^{4}$ Grupo Neurolamb, Biología funcional y Ciencias de la Salud, Universidad de Vigo (Spain), 36310 As Lagoas-Marcosende, Spain. ${ }^{5}$ Department of Agricultural, Forest and Food Sciences, University of Torino, Largo Paolo Braccini 2, 10095 Grugliasco, Turin, Italy. ${ }^{6}$ Instituto Pirenaico de Ecología (CSIC), Dpto. Conservación de Ecosistemas Naturales, Avda. Montaña
\end{abstract} S/N, Zaragoza, 50016 Zaragoza, Spain

\section{Author contributions}

Conception and design of the experiments: M.C. Martínez. Survey for plant material: M.C. Martínez and J.L. Santiago. Botanical description: M.C. Martínez, D. Gómez-García, P. Gago. STMS analysis: V. Scariot, M.Caser, J.L. Santiago, P. Gago. Histological study of the petals: R. Álvarez-Nogal, Molíst, S. Boso, Martínez M.C. Analysis of petal volatile compounds: M.-E. De Vega, I. ÁlvarezAcero, M. Martínez-Bartolomé, S. Boso, M.C. Martínez. Data analysis and interpretation: M.C. Martínez, J.L. Santiago, S. Boso, P. Gago, I. Álvarez-Acero, M.E. De Vega2, M. Martínez-Bartolomé, R. Álvarez-Nogal, P. Molíst, M. Caser, V. Scariot, D. Gómez-García. Drafting of the manuscript: M.C. Martínez, J.L. Santiago. Revising the manuscript critically for important intellectual content and providing extensive guidance to the execution of the project: M.C. Martínez, J.L. Santiago, S. Boso, P. Gago, I. Álvarez-Acero, M.E. De Vega, M. Martínez-Bartolomé, R. Álvarez-Nogal, P. Molíst, M. Caser, V. Scariot, D. GómezGarcía
\end{abstract}

\section{Data availability}

The data supporting the results presented in this work are available in the supplementary information

\section{Conflict of interest}

The authors declare that they have no conflict of interest.

Supplementary Information accompanies this paper at (https://doi.org/ 10.1038/s41438-020-0266-8).

Received: 16 September 2019 Revised: 6 February 2020 Accepted: 12 February 2020

Published online: 01 April 2020

\section{References}

1. Fougère-Danezan, M., Joly, S., Bruneau, A., Gao, X.-F. \& Zhang, L.-B. Phylogeny and biogeography of wild roses with specific attention to polyploids. Ann Bot.-Lond. 115, 275-291 (2015).

2. Rehder, A. Manual of cultivated trees and shrubs: hardy in North America: exclusive of the subtropical and warmer temperate regions. 2nd ed. rev. and enl (Blackburn Press, 2001).

3. Decaisne, J. \& Naudin, C. H. Manuel de l'Amaterur des jardins. Traité Général d'horticulture. Tome II. (Librairie de Firmin Didot Frères, Fils et Cie, 1862).

4. Guillemeau, J. Histoire naturelle de la rose (L'imprimerie de Vatar-Jouannet, 1800).

5. Lindley, J. Rosarum monographia, or, a Botanical Hystory of Roses (Printed for James Ridgway, 1820)

6. Redouté, P. \& Thory, C. A. Les Roses. Tome second ( $L^{\prime}$ imprimerie de Firmin Didot, 1821).

7. Cranston, J. Cultural directions for the rose (W. Rowbottom, 1857).

8. Koopman, W. J. M. et al. AFLP markers as a tool to reconstruct complex relationships: a case study in Rosa(Rosaceae). Am. J. Bot. 95, 353-366 (2008).

9. Liorzou, M. et al. Nineteenth century French rose (Rosa sp.) germplasm shows a shift over time from a European to an Asian genetic background. J. Exp. Bot. 67, 4711-4725 (2016).

10. Bubani, P. Flora Pyrenaea per ordines naturales gradatim digesta. Vols. I-IV (Ed. Ulricus Hoeplius, 1897-1902).

11. Montserrat, P., Daniel Gómez, D., Ferrández, J. V. \& Bernal, M. Rosas de Aragón y tierras vecinas. 2nd edition. (Colección Monografías de Botánica Ibérica, $n^{\circ}$ 14. Jolube Consultor Botánico y Editor, 2016).

12. Mayor-López, M. \& Díaz-González, E. La flora asturiana (Colección Popular Asturiana Ayalga, 1977).

13. Fernández Prieto, J. A. \& Vázquez, V. M. Diversidad y Fitogeografía de los rosales silvestres (género rosa L.) en la reserva de Biosfera de Somiedo (Asturias, España). Boletín Cienc. Naturales R. I. D. E. A. 50, 311-331 (2009).

14. Sánchez-Corominas, T., Fernández-Prieto, J. A. \& Vázquez, V. M. Primeras evidencias de la naturalización de Rosa rugosa Thunberg Ex Murray, en el Principado de Asturias (España). Boletín Cienc. Naturales R. I. D. E. A. 50, 303-310 (2009).

15. Boutelou, C. \& Boutelou, E. Tratado de las flores: En que se explica el método de cultivar las que sirven para adorno de los jardines (Imprenta de Villalpando, 1804).

16. International Union for the Protection of New Varieties of Plants. Rose UPOV Code: ROSA Rosa L. Guidelines for the conduct of tests for distinctness, uniformity and stability- TG/11/8 Rev (2010).

17. Scariot, V., Akkak, A. \& Botta, R. Characterization and genetic relationships of wild species and old garden roses based on Microsatellite analysis. J. Am. Soc. Hort. Sci. 131, 66-73 (2006).

18. Caser, M., Torello Marinoni, D. \& Scariot, V. Microsatellite-based genetic relationships in the genus Camellia: potential for improving cultivars. Genome 53, 384-399 (2010).

19. Kiani, M. et al. Microsatellite analysis of Iranian Damask rose (Rosa damascena Mill.) germplasm. Plant Breed. 129, 551-557 (2010).

20. Farooq, A. et al. Microsatellite analysis of Rosa damascena from Pakistan and Iran. Hortic. Environ. Biotechnol. 54, 141-147 (2013).

21. Hibrand Saint-Oyant, L. et al. A high-quality genome sequence of Rosa chinensis to elucidate ornamental traits. Nat. Plants 4, 473-484 (2018).

22. Smulders, M. J. M. et al. In the name of the rose: a roadmap for rose research in the genome era. Hortic. Res. 6, 65 (2019).

23. Saint-Lary, $\mathrm{K}$. et al. Metabolomics as a tool for the authentication of rose extracts used in flavour and fragrance area. Metabolomics 12, 49 (2016).

24. Xiao, Z., Luo, J., Niu, Y. \& Wu, M. Characterization of key aroma compounds from different rose essential oils using gas chromatography-mass spectrometry, gas chromatography-olfactometry and partial least squares regression. Nat. Prod. Res. 32, 1567-1572 (2018).

25. Yassa, N., Masoomi, F., Rohani, Rankouhi, S. E. \& Hadjiakhoondi, A. Chemical composition and antioxidant activity of the extract and essential oil of Rosa damascena from Iran, Population of Guilan. Daru. J. Pharm. Sci. 17, 175-180 (2009).

26. Kovacheva, N., Rusanov, K. \& Atanassov, I. Industrial cultivation of oil bearing rose and rose oil production in Bulgaria during 21st century, directions and challenges. Biotechnol. Equip. 24, 1793-1798 (2010).

27. Sharma, S. \& Kumar, R. Influence of harvesting stage and distillation time of Damask rose (Rosa damascena Mill.) flowers of essential oil content and composition in the Western Himalayas. J. Essent. 21, 92-102 (2018). 
28. De la Rosa, R., James, C. M. \& Tobutt, K. R. Isolation and characterization of polymorphic microsatellites in olive (Olea europaea L.) and their transferability to other genera in the Oleaceae. Mol. Ecol. Notes 2, 265-267 (2002).

29. Esselink, G. D., Smulders, M. J. M. \& Vosman, B. Identification of cut rose (Rosa hybrida) and rootstock varieties using robust sequence tagged microsatellite site markers.Theor. Appl. Gen 106, 277-286 (2003).

30. Peakall, R. \& Smouse, P. E. GenAlEx 6: genetic analysis in Excel. Population genetic software for teaching and research. Mol. Ecol. Notes 6, 288-295 (2006).

31. Kiernan, J. A. Histological and Histochemical Methods, 4th edition (Scion Publishing Ltd., 2008).

32. Tabaei-Aghdaei, S. R. et al. Morphological and oil content variations amongst Damask rose (Rosa damascena Mill.) landraces from different regions of Iran. Sci. Hortic. 113, 44-48 (2007).

33. Farooq, A., Khan, M. A., Ali, A. \& Riaz, A. Diversity of morphology and oil content of Rosa damascena landraces and related Rosa species from Pakistan. Pak. J. Agr. Sci. 48, 177-183 (2011).

34. Roberts, A. V., Gladis, Th \& Brumme, H. DNA amounts of roses (Rosa L.) and their use in attributing ploidy levels. Plant Cell Rep. 28, 61-71 (2009).

35. Farooq, A. et al. Cross compatibility in various scented Rosa species breeding. Pak. J. Agric. Sci. 53, 863-869 (2016)

36. Stubbs, J. M. \& Francis, M. J. O. Electron microscopical studies of rose petal cells during flower maturation. Planta Med. 20, 211-218 (1971).

37. Bergougnoux, $\vee$. et al. Both the adaxial and abaxial epidermal layers of the rose petal emit volatile scent compounds. Planta 226, 853-866 (2007)

38. Sulborska, A. \& Weryszko-Chmielewska, E. Characteristics of the secretory structures in the flowers of Rosa rugosa Thunb. Acta Agrobot. 67, 13-24 (2014). 2014
39. Semyonovna, Y. F., Shpichka, A. I., Presnyakova, Y. V. \& Mezhennaya, N. A Processes of essential oil accumulation in petals of Rosa (Rosaceae) and mycelium Eremothecium (Eremotheciaceae). Bull. SNBG 118, 25-33 (2016).

40. Baudino, S. et al. Production and Emission of Volatile Compounds by Petal Cells. Plant Signal Behav. 2, 525-526 (2007).

41. Nedeltcheva-Antonova, D., Stoicheva, P. \& Antonov, L. Chemical profiling of Bulgarian rose absolute (Rosa damascena Mill.) using gas chromatography-mass spectrometry and trimethylsilyl derivatives. Ind. Crops Prod. 108, 36-43 (2017).

42. Zhao, C. Y. et al. Assessment of the key aroma compounds in rose-based products. J. Food Drug Anal. 24, 471-476 (2016).

43. Gorji, A. Pharmacological treatment of headache using traditional Persian medicine. Trends Pharmacol. Sci. 24, 331-334 (2003).

44. Boskabady, M. H., Shafei, M. N., Saberi, Z. \& Amini, S. Pharmacological effects of Rosa damascena. IJBMS 14, 295-307 (2011).

45. Valiakos, E., Marselos, M., Sakellaridis, N., Constantinidis, T. \& Skaltsa, H. Ethnopharmacological approachtotheherbalmedicines of the "Antidotes" in Nikolaos Myrepsos' Dynameron. J. Ethnopharmacol. 163, 68-82 (2015).

46. Baser, K. H. C. Rose Mentioned in the Works of Scientists of the Medieval East and Implications in Modern Science. Nat. Prod. Commun. 12, 1327-1330 (2017)

47. Maurya, R., Srivastava, S., Kulshreshta, D. K. \& Gupta, C. M. Traditional remedies for fertility regulation. Curr. Med. Chem. 11, 1431-1450 (2004).

48. Fernandes, L., Casal, S., Pereira, J. A., Saraiva, J. A. \& Ramalhosa, E. Edible flowers: a review of the nutritional, antioxidant, antimicrobial properties and effects on human health. J. Food Compost Anal. 60, 38-50 (2017).

49. Mohebitabar, $\mathrm{S}$. et al. Therapeutic efficacy of rose oil: a comprehensive review of clinical evidence. Avicenna J. Phytomed. 7, 206-213 (2017). 